\title{
An Analysis of Narrative Techniques and Creative Skills in the Documentary "Four Springs"
}

\author{
Yuling Chen \\ Nanchang Hangkong University, Nanchang 330000, Jiangxi, China \\ Email: 2154896350@qq.com
}

\begin{abstract}
In 2019, the documentary "Four Springs" was released in Chinese cinemas. Even with little publicity and competition from other blockbusters, the film has done remarkably well relative to documentary films. In addition, "Four Springs" won the honor of the best documentary in the 12th First Youth Film Festival that year, and this documentary based on the ordinary daily family life attracted wide attention. "Four Springs" focuses on the family life, focuses on showing the most real and simple pictures of life, it deeply excavates the thoughts between families that are difficult to cut off, and shows the audience the author's silent talk about his hometown, his family and his relatives with the pictures that reflect the documentary aesthetics. This paper will analyze "Four Springs" from two aspects of narrative techniques and creative skills.
\end{abstract}

Keywords: documentary, "Four Springs", narrative technique, documentary creation

\section{Introduction}

The story structure of the documentary "Four Springs" is just like its name. It is a story that takes place in four different springs, specifically, the story of the director's family in each spring from 2013 to 2016. The director focused his camera on his parents, who were nearly seventy years old. He focused on the scene when the two parents met with their children every spring, slowly removed the unknown sadness of the seemingly cheerful old people on the back of life. In addition, the lens with the director of the parents, showing the town's simple, quiet but full of life breath country life, and people's labor, singing, eating, rest, drew out a light but very real and long life picture scroll. It is like a gaze which not staring at the main character, but seriously gaze at our real life, so that we can not help thinking and aftertaste the true life.

The film not only on narrative with exquisite design, and on the creation means . There are intent on the idea of the topics of the family of the documentary, it has neither abandon the family film that inherently gentle tone, at the same time has a dramatic plot tension, although the first film of Lu Qingyi works as a director, there are still many insufficient place. However, this documentary is still worthy of in-depth analysis and research.

\section{Narrative techniques}

First of all, the film has a profound design idea in the narrative structure and the narrative subjectIn terms of structure, four different springtime narrations are used to show the annual changes of a family, which is a very poetic aesthetic narrative method.Spring, in the field of film creation, is not only a seasonal meaning of the word.Almost all poets have poems about spring, who using the beautiful time or scenery in spring to express their feelings. Therefore, the director chose the four spring as the time of story, so that the story itself has a thoughtful tone. Secondly, spring is a season of beginnings and departures. Farewell to the cold and solemn winter, people start the New Year in the spring. It is also a time to go out when the children leave their parents, leave home, this kind of emotion is the most suitable for display family emotional change. People can more deeply feel emotional fluctuations, Because this is a scenario that every one of them has actually experienced.

In fact, the spring of four different years is very long in the time span, but for the display of family life, it is indeed the best way to reflect the change of life and the mood of the characters.Because for a life with no end in time, most of the wonderful details are hidden in the quiet life. If we want to find, we need a long enough piece to find.In this film, the story of each spring is a change of mood. In the first spring, the director took us into a small town in Guizhou province, and we got to know the main character of the film, the director's parents. The emotional tone of the film is set by the narration of the parents and their life and work scenes, also illuminates the theme as discover the joys and sorrows of a real family. As the story continues in the second spring, We learn its irreconcilable conflict with the family's past and reality. But the director's parents are still able to maintain a peaceful state of mind, let us understand how this family's emotional bond is so strong. Then the plot takes a sharp turn, reaching its emotional climax in the third spring, when the director's sister dies of illness. As for the documentary, the change here is a great shock to the audience, just like the shock to the director's parents when they 
heard the news of their daughter's death. In the previous story, the audience constructed a dull but close family relationship, and then the expectation of family perfection was hit. But after deep thinking, isn't that the real life? As a result, the plots of each spring are treated as dramatic means without affecting the authenticity that the documentary seeks. In terms of the narrative theme, the film chose the director's parents as a narrative subject, while the director hid behind the camera and did not participate in the narrative. As a documentary featuring a private narrative, the protagonist personally tells about his life and his family, which creates a scene of dialogue between the two. The audience through the picture, to see them show the most real life. All the life scenes are narrated without alienating the audience, such as making sausages, talking about Musical Instruments, or parents climbing mountains. It is precisely because of this that we can more feel the real emotion of the director's family, and can follow their pulse together.

\section{The creative skills}

The film and television space is poeticized. A documentary about private family images, if not handled well, is just a complicated daily life in an ordinary family, which can easily make people feel dull. In this point, the video language of the film "Four Springs" has achieved a different breakthrough in documentary creation. The live-streaming video diary in the film has its own unique aesthetic temperament. The film juxtaposes the parents' daily lives. There are also four repeated figures -- the swallow, the father, the mother and the grey sky. These repeated audio-visual images emphasis, which makes the audience feel a warm, bitter and sad mood. In addition, the unique spatial image sense of this film is composed of threedimensional family space and infinitely extending heaven and earth. We can see the square courtyard in the sky, the circular pool with goldfish swimming, the roof garden in the spring, the space-time relationship between the light and shadow. The walking through the mountains and jungles resembled scenes from Mr. Kore-eda's films, and the long shots of the singing along the stream at one point felt more like a feature film than a documentary. The overall tone of the film is simple, in the film long shots, follow up, the same sound are widely used. André Bazin, a man who is known as the father of French New Wave film, whose view of the evolution of film language believes that montage will cut off the reality of time and space in the film, and long shots have more recording and revealing functions. "Four Springs" cleverly uses some long takes, such as parents drink cross glasses of wine, Mother leisurely singing folk songs, father followed behind.The words, deeds and expressions of the parents were truthfully recorded, and no pictures were omitted due to the cutting of the montage, which truly showed the lively characters of the parents. Most of the cameras adopt a head-up Angle, with the perspective of onlookers to get close to the daily life of the two elderly people. At the same time, the director adds meaning to the picture content through the choice of screen space. Specifically, the film uses the contrast factors in the picture to form a metaphor, so that the picture content is divorced from its own meaning and becomes a symbol of meaning. Within the enclosed space, the wall between the two rooms serves as a tool to divide the image presented below the camera in two. On the left, mother works at the sewing machine while father clips videos at the computer. The fixed long lens seems to record the parents' daily life at the same time, but in fact it is to express the parents' hobbies in different Spaces. The presentation of this picture symbolizes both the material and the spiritual aspects of the parents' life. The left side is the material, which is necessary to sustain life. On the other side is the spiritual, the joy of life. Such a cinematic space expression makes these seemingly trivial family daily life more ritualistic under the lens, adding romance and poetry to the film

Polysemous implication. Image language endows the picture with creative ideographic function, and every shot is a new creation.In the documentary "Four Springs", scenes such as patio, sausage and spring swallow are given different connotations each time.In the opening scene of the film, father is running in the middle of the patio. In the second scene, mother is cleaning the fish pond at the bottom of the patio. In the third scene, parents are standing at the bottom of the patio. Vertical patios juxtapose three levels that are patio ground kitchen, dining table, fish pond. The music of parents singing and dancing, the offering of ancestors before eating, the leaving of a set of chopsticks for the sister, these details are obviously beyond the scope of reality, and give these daily life a special meaning. To this pair of old people, the world is the old house of lu jia and the sky above the courtyard however, but insipous life is "written" by them however full romance and poetic poetry are in this small world day after day. The courtyard here abandoned the solidified understanding of "looking at the sky from a well", looking up at the starry sky, people can see the hope of optimism and open-minded life. Spring Swallow appears four times in the film, and these also symbolize different meanings in different periods. For example, in the first spring, the swallow flew on the golden wedding day of his parents, and the swallow at this moment carries the meaning of "joy" in his documentary. In the second spring, the screen shows the mother busy in the kitchen, while the voice of the father announces the arrival of the swallows. The swallow is now a harbinger of spring. In the third spring, the scene of the swallows' return is shown through the 2012 video, which is used to render the sense of memory. The fourth spring, the swallow flew back to the nest in the pop head and the lens frozen in the parents smile, meaning the return of spring, life 
continues. Sausage, as the carrier of traditional farming civilization, has been passed down to the present in the way of taste. Smoked sausage is waiting for children who are about to return home. It is an essential meal at the reunion dinner and a gift for children who leave home. In the film, the three children leave their hometown to seek their dreams, which is a normal migration in modern society. For the children, the sausage means the attachment to the hometown, while for the parents, it means the care for the children. There are three scenes of sausages being smoked in the film. Like writing couplets, it has a strong sense of ritual. For the Lu family, sausage is a "tradition", a ritual of New Year's day . His mother told qingyi Lu: "In the future, if we are not here, you should remember the family tradition." The death of her sister in the third spring deprived the family of the motivation to smoke sausages and made life tasteless. The three smoked sausages in the film are different circumstances, but the sausages are all turned into the hope of family reunion.

\section{Summary}

Film, as a special imaging medium, can not only reproduce the realism such as Siegfried Krakauer's "material restoration theory" and Andre Barzan's "film ontology", but also integrate the situation in the image like Wang Guowei's "scenes and feelings". "Four Springs" is a private home video documentary based on many aspects of real life. For the director, it is a special gift to his parents, and for the society, it reflects the return of humanistic care. Art comes from life and at the same time is above life. By recording the daily life of his parents and using artistic expression means such as montage, sound, picture composition, symbol and metaphor, "Four Springs" accurately and vividly depicts the true face of life. From the film, we can understand the harmonious atmosphere of this ordinary family, and their attitude of life into a poem. The film uses artistic techniques to express the love of real life, which highlighting the romance and poetry of ordinary life.

\section{References}

[1] Pan Mengge. "True Expression" of Hand-held Shooting -- Interpretation of the image language of Four Springs [J]. Film and television production, 2019,25(12):85-89.

[2] Peng Ji. Film and Television Aesthetics [M], Peking University Press, 2009, p.43.

[3] Tian Hui. Image interpretation based on the recording media of Four Springs [J]. Journal of Popular Literature and Art, 2019,(22):191-192. 